\title{
Prospect of low-cost energy conservation in residential energy consumption
}

\author{
Ruchi Tyagi ${ }^{1}$, Suresh Vishwakarma² \\ ${ }^{1}$ Department of General Management, School of Business, University of Petroleum and Energy Studies, Dehradun, India \\ ${ }^{2}$ Department of Utilities Engineering, University of Trinidad and Tobago, Canada
}

\begin{tabular}{|c|c|}
\hline Article Info & ABSTRACT \\
\hline Article history: & The energy sector of trinidad and tobago (T\&T), with its nationally determined \\
\hline Received Oct 10, 2020 & literature. The review paper aims to identify the prospects of low-cost energy \\
\hline Revised Aug 23, 2021 & conservation measures in the residential sector of $\mathrm{T} \& \mathrm{~T}$. The review follows a \\
\hline Accepted Sep 30, 2021 & $\begin{array}{l}\text { four-step review methodology to serve as a basis for creating policy and } \\
\text { practice guidelines. First, review articles are checked for their quality on a 5- }\end{array}$ \\
\hline Keywords: & $\begin{array}{l}\text { point scale on the mixed methods appraisal tool (MMAT) to check the quality } \\
\text { of review articles. Second, Microsoft Excel, R (RQDA) package, and Voyant }\end{array}$ \\
\hline Carbon emission & tools have been used to index code, analyse, and visualise data. The research \\
\hline Fneroy challenoes & trends on small islands developing states (SIDS) energy aspect in general and \\
\hline Energy challenges & $\mathrm{T} \& \mathrm{~T}$ specifically highlight the critical role of energy challenges related to \\
\hline Energy conservation & economic and social development, emphasising technology, infrastructure \\
\hline Residential consumption & $\begin{array}{l}\text { development, and funds availability. Awareness of low-cost energy } \\
\text { conservation measures has a high prospect in reducing residential consumption } \\
\text { and balancing demand-side management. This paper contributes to facilitating } \\
\text { policy direction on energy efficiency and energy conservation for T\&T and } \\
\text { other SIDS. }\end{array}$ \\
\hline
\end{tabular}

This is an open access article under the CC BY-SA license.

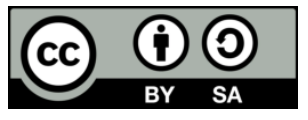

\section{Corresponding Author:}

Ruchi Tyagi

Department of General Management

School of Business, University of Petroleum and Energy Studies

Dehradun 248001, India

Email: rtyagi@ddn.upes.ac.in

\section{INTRODUCTION}

There is a strong correlation between the total economic output of nations (measured by their GDP) and their $\mathrm{CO}_{2}$ emissions [1]. Higher energy consumption helps boost economic growth but at the cost of environmental degradation [2]-[4]. Economic analysts familiar with T\&T insist that economic development is necessary for attaining sustainable development and climate change [5]-[7]. However, the reality of the Caribbean, on the "Economic Periphery of the World Capitalist Economy", is limited economic development opportunities [8]. The economic model for lesser developed countries concludes limited options as "A low initial level of environmental quality forces resource users to discount the future heavily ... poor people faced with marginal environmental conditions have no choice but to opt for immediate benefits at the expense of the long-run sustainability of their livelihoods". $60 \%$ of the world's population will live in cities by 2030 , up from about $50 \%$ today. Modern cities account for $70 \%$ of global energy use and energy-related GHG emissions. The building sector accounts for around one-third of the final energy consumption globally and more than half of electricity demand. Its energy demand could be shrunk by, for instance, retrofitting existing buildings with more efficient heating and cooling technology and switching to efficient lighting and other 
electrical appliances. This energy efficiency initiative will potentially result in an annual savings of US\$ 555770 billion [9]-[11], which is $40 \%$ of the global energy consumption and more than $30 \%$ of the global carbon dioxide [12]. The decrease in peak demand and carbon emission reduction go hand in hand with low residential electricity consumption [13]. Air-conditioning systems, lights, water heating systems, receptacle mount loads used in the building should be energy efficient [14]. T\&T, in response to Paris Agreement, has set its NDCs on low carbon development. Around 34.9\% of T\&T's GDP is from the energy sector. Further, it accounts for about $80 \%$ of exports. The energy sector is integral to the long-term economic growth and development of T\&T, contributing significantly to government revenue, export earnings, and GDP [15]. The energy consumption at $\mathrm{T} \& \mathrm{~T}$ is a significant contributor to government revenue. Table 1 presents an overview of the $\mathrm{T} \& \mathrm{~T}$ electricity sector per the Caribbean Center for Renewable Energy and Energy Efficiency.

Table 1. Trinidad \& Tobago electricity sector overview (2020)

\begin{tabular}{cccccc}
\hline $\begin{array}{c}\text { Total Installed } \\
\text { Capacity }\end{array}$ & Peak Demand & Total Generation & $\begin{array}{c}\text { Renewable } \\
\text { Share }\end{array}$ & $\begin{array}{c}\text { Transmission \& Distribution } \\
\text { Losses }\end{array}$ & $\begin{array}{c}\text { Energy } \\
\text { Access }\end{array}$ \\
\hline 75 MW (T\&TEC) & $\begin{array}{c}1319 \mathrm{MW} \\
(2018)\end{array}$ & $\begin{array}{c}9324 \mathrm{GWh} \\
(2018)\end{array}$ & $0 \%$ & $8 \%$ & $100 \%$ \\
$2080 \mathrm{MW}$ (IPPs) & & & $0 \%$ & 8 \\
\hline
\end{tabular}

The Trinidad and Tobago electricity commission (T\&TEC) is the sole transmission and distribution company serving Trinidad and Tobago. Projections on revenue from energy are increasing as T\&TEC's total customer base is growing on an average annual compounded rate of $1.7 \%$, from 503,871 customers in 2020 to 539,685 in 2024 and 584,453 in 2029 . The increase is marginally less than the growth rate of $1.8 \%$ reported in 2019's forecast. In 2020, the commission expects to serve almost 503,871 customers, of which 443,411 willbe residential, 60,376 will be commercial and small industrial, and 39 will be large industrial. By 2029 these customer numbers are expected to be 584,453, out of which 512,160 residential, 72,209 commercial and small industrial and 39 large industrial. The forecast window is consistent with 2019's forecast, there are no new large industrial customers, but the residential customers are growing exponentially within the forecast window. Therefore, there is a fair chance of energy conservation in the residential sector. However, the dearth of literature on energy conservation measures landscape in relevance to T\&T derives the need for review. This review paper aims to explore the possibilities for low energy conservation measures in the residential sector of Trinidad and Tobago on the above background.

\section{RESEARCH METHOD}

The literature reviewer collects information representing the data making it equivalent to a research study [16]. Review Methodology functions as a source to create recommendations for policy and practice [17]. Literature Review Methodology Process flowchart includes review design, review of content, analysis of findings and writing discussion, conclusion and implication from review [17]. The four-step review methodology befits the paper's purpose of identifying the prospects of low-cost energy conservation measures as a basis for knowledge development in energy consumption and create energy conservation guidelines for policy and practice [18], [19]. The MMAT tool assessment of included literature highlights the quality of literature review for method, scope and sequence [20]. The search selection process and exclusion inclusion criterion are established. Authors used two separate search strings- (i) "T\&T" (title), "Energy Consumption" (abstract), (ii) "Energy Conservation Measures" (title), and "T\&T" (abstract). Table 2 abstracts the guiding question to retain review quality [17]. Figure 1 summarises upon review process. Predominantly 3083 publications appeared, leading to a sample of 19 publications fulfilling the criterion of inclusion and exclusion.

The year wise split of 19 study in [22]-[40] under review is as follows: $03(2020)+02(2019)+06(2018)+$ $02(2017)+03(2016)+02(2014)+01(2013)$.

Quality of the articles under review; mixed methods appraisal tool (MMAT) is a reliable content evaluation tool [20]. Division of studies is on the methods used, further into descriptive, random, and nonrandom studies shows in Tables 3, 4, 5. The final evaluation is done on "Yes (Y), No (N) and Cannot tell (C)" rating evaluation is done on the scoring scale of five, discouraging the calculation of the total score. The assessment report on the quality of qualitative and quantitative methods was appropriate to address the coherence between data source, analysis, interpretation, and samples' substantial representation of the target population [41]. In mixed method publications, qualitative and quantitative components are appropriately integrated. However, one publication has shown inconsistency and divergence between the qualitative and quantitative results. 
Conceptualisation process; qualitative researchers think conceptually via an examination of the qualitative methodological literature [41], [42]. Figure 2 illustrates the conceptual lens using open-source software-voyant tool. Table 6 shows the conceptualisation process [42]. The Microsoft Excel summary sheet of 19 studies under methodological review to derive the core concept included 163 transcripts. That led to 142 preliminary thoughts generating 103 Open Codes, Forming 58 initial and 28 Final categories, ten subthemes, four themes, two Potential Concepts and a Core-Concept. The association's indexing code is analysed using open-source software R (RQDA package) [43].

Table 2. Review process and guiding questions

\begin{tabular}{|c|c|}
\hline \multicolumn{2}{|c|}{ Process } \\
\hline $\begin{array}{l}\text { Step 1. Design } \\
\text { - If this review on LCECM is needed, will it increase } \\
\text { awareness of sustainable development goals, particularly } \\
\mathrm{CO}_{2} \text { emissions and climate change in the residential sector? } \\
\text { - Is there a prospect to reduce carbon footprint by LCECM? } \\
\text { - Does the review identify recent research trends on energy } \\
\text { aspects and explores how literature addresses the literature. } \\
\text { - Set the search inclusion criteria from } 2013 \text { to } 2021 \text { for peer- } \\
\text { reviewed academic journals available online in English. } \\
\text { The article's relevance to energy conservation measures to } \\
\text { search in SDG7, energy conservation, energy efficiency, } \\
\text { clean technology, sustainability, social science, and the } \\
\text { environmental science area }\end{array}$ & $\begin{array}{l}\text { Step 2. Conduct } \\
\text { - } \quad \text { At the outset of search design, we search using two distinct } \\
\text { sets of search strings. } \\
\text { - The electronic database of } 3083 \text { using funnel strategy (Figure } \\
\text { 1) leads to a sample size of } 19 \text { publications. } \\
\text { - Check of included study for final exclusion and quality over } \\
\text { MMAT tool. } \\
\text { Step 3. Analysis } \\
\text { - } \quad \text { Abstraction and Indexing Codes as per review aim } \\
\text { - Pointwise presentation of findings and discussion given } \\
\text { relevant study, expert opinion, and government reports [21]. } \\
\quad \text { Step 4. Forming and writing the review } \\
\text { - The review concludes on the discussion in application to the } \\
\text { purpose of the review. } \\
\text { The implications on the subject matter, available research } \\
\text { literature and policy is the contribution of the review }\end{array}$ \\
\hline
\end{tabular}

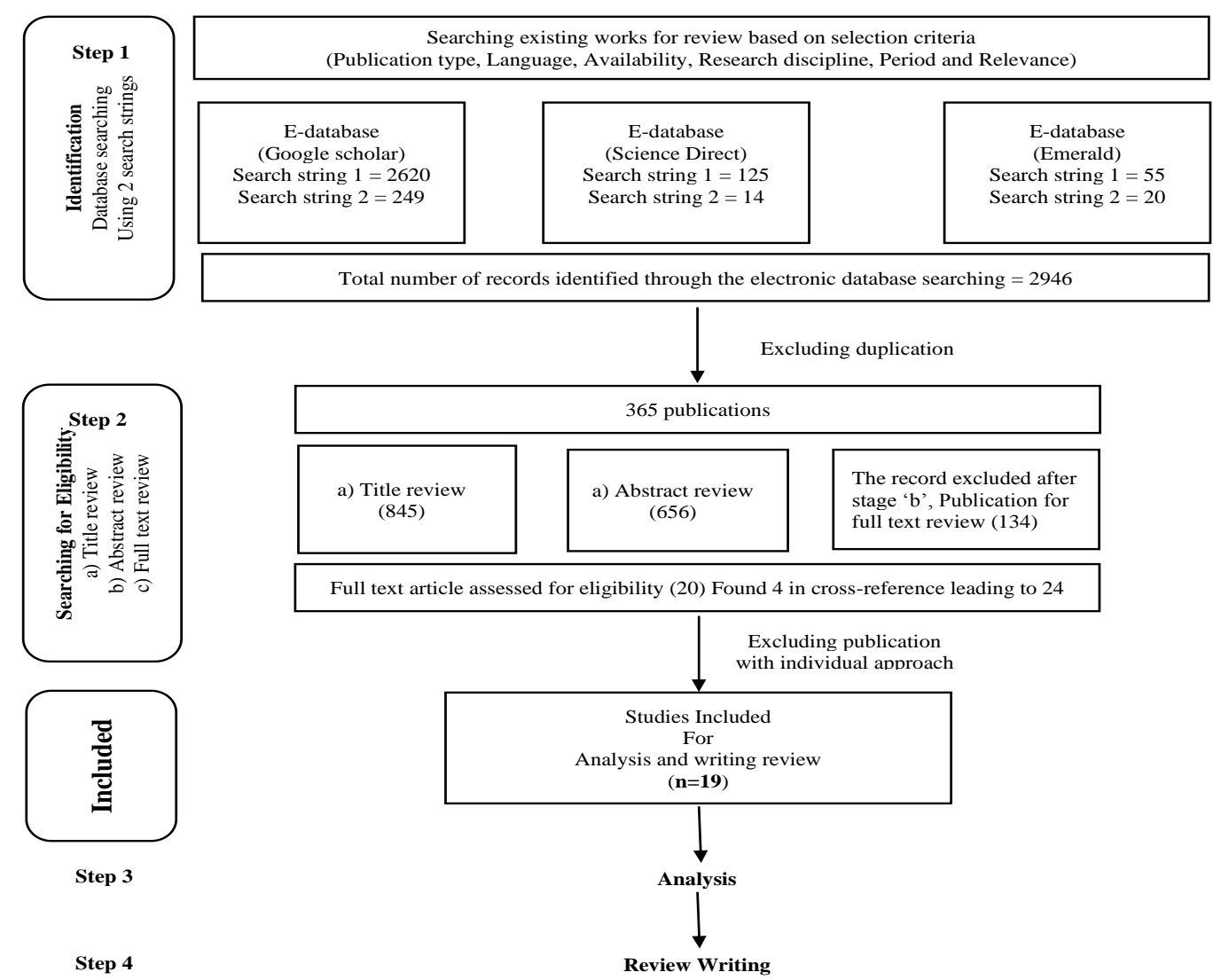

Figure 1. The review process 


\begin{tabular}{|c|c|c|c|c|c|}
\hline $\begin{array}{l}\text { Ref } \\
\text { No }\end{array}$ & $\begin{array}{l}\text { 1. Is the qualitative } \\
\text { approach appropriate } \\
\text { to answer the } \\
\text { research question? }\end{array}$ & $\begin{array}{l}\text { 2. Are qualitative data } \\
\text { collection methods } \\
\text { adequate to address the } \\
\text { research question? }\end{array}$ & $\begin{array}{l}\text { 3. Are findings } \\
\text { derived } \\
\text { substantially } \\
\text { from the data. }\end{array}$ & $\begin{array}{c}\text { 4. Is the } \\
\text { interpretation of } \\
\text { results } \\
\text { demonstrated by } \\
\text { the data? }\end{array}$ & $\begin{array}{l}\text { 5. Is there coherence } \\
\text { between data source, } \\
\text { data collection, } \\
\text { analysis and } \\
\text { interpretation }\end{array}$ \\
\hline 30 & $\mathrm{Y}$ & $\mathrm{Y}$ & $\bar{Y}$ & $\mathrm{Y}$ & $\mathrm{Y}$ \\
\hline 33 & Y & $\mathrm{Y}$ & $\mathrm{Y}$ & Y & $\mathrm{Y}$ \\
\hline 22 & $\mathrm{Y}$ & $\mathrm{Y}$ & $\mathrm{Y}$ & $\mathrm{Y}$ & $\mathrm{Y}$ \\
\hline 23 & $\mathrm{Y}$ & $\mathrm{Y}$ & $\mathrm{Y}$ & $\mathrm{Y}$ & $\mathrm{Y}$ \\
\hline 28 & $\mathrm{Y}$ & $\mathrm{Y}$ & $\mathrm{Y}$ & Y & $\mathrm{Y}$ \\
\hline 31 & Y & $\mathrm{Y}$ & Y & $\mathrm{Y}$ & $\mathrm{Y}$ \\
\hline 35 & Y & $\mathrm{Y}$ & Y & Y & $\mathrm{Y}$ \\
\hline 37 & $\mathrm{Y}$ & $\mathrm{Y}$ & $\mathrm{Y}$ & $\mathrm{Y}$ & $\mathrm{Y}$ \\
\hline 40 & $\mathrm{Y}$ & $\mathrm{Y}$ & $\mathrm{Y}$ & $\mathrm{Y}$ & $\mathrm{Y}$ \\
\hline
\end{tabular}

Table 4. MMAT quality assessment table (quantitative methods) ( $\mathrm{n}=7$ )

\begin{tabular}{cccccc}
\hline Ref. No & $\begin{array}{c}\text { 1. Is the sampling } \\
\text { strategy appropriate } \\
\text { to address the } \\
\text { research question? }\end{array}$ & $\begin{array}{c}\text { 2. Do samples } \\
\text { substantially } \\
\text { represent the target } \\
\text { population? }\end{array}$ & $\begin{array}{c}\text { 3. Are the } \\
\text { measurement } \\
\text { methods fitting? }\end{array}$ & $\begin{array}{c}\text { 4. Is the risk of } \\
\text { non-bias } \\
\text { response low? }\end{array}$ & $\begin{array}{c}\text { 5. Is the analysis (a } \\
\text { statistical tool used) } \\
\text { suitable to answer the } \\
\text { research question? }\end{array}$ \\
\hline 27 & $\mathrm{Y}$ & $\mathrm{Y}$ & $\mathrm{Y}$ & $\mathrm{Y}$ & $\mathrm{Y}$ \\
24 & $\mathrm{Y}$ & $\mathrm{Y}$ & $\mathrm{Y}$ & $\mathrm{Y}$ & $\mathrm{Y}$ \\
34 & $\mathrm{Y}$ & $\mathrm{Y}$ & $\mathrm{Y}$ & $\mathrm{Y}$ & $\mathrm{Y}$ \\
36 & $\mathrm{Y}$ & $\mathrm{Y}$ & $\mathrm{Y}$ & $\mathrm{Y}$ & $\mathrm{Y}$ \\
38 & $\mathrm{Y}$ & $\mathrm{Y}$ & $\mathrm{Y}$ & $\mathrm{Y}$ & $\mathrm{Y}$ \\
29 & $\mathrm{Y}$ & $\mathrm{Y}$ & $\mathrm{Y}$ & $\mathrm{Y}$ & $\mathrm{Y}$ \\
26 & $\mathrm{Y}$ & $\mathrm{Y}$ & & & Y \\
\hline
\end{tabular}

Table 5. MMAT quality assessment table (mixed methods) $(\mathrm{n}=3)$

\begin{tabular}{|c|c|c|c|c|c|}
\hline $\begin{array}{c}\text { Ref. } \\
\text { No }\end{array}$ & $\begin{array}{l}\text { 1. Rationale to use } \\
\text { mixed approach } \\
\text { design is } \\
\text { appropriate to } \\
\text { answer the } \\
\text { research question. }\end{array}$ & $\begin{array}{l}\text { 2. Are the qualitative } \\
\text { and quantitative } \\
\text { components } \\
\text { appropriately } \\
\text { integrated to answer } \\
\text { the research question? }\end{array}$ & $\begin{array}{l}\text { 3. Are Findings of } \\
\text { the integration of } \\
\text { qualitative and } \\
\text { quantitative } \\
\text { components } \\
\text { substantially } \\
\text { addressed? }\end{array}$ & $\begin{array}{l}\text { 4. Is inconsistency } \\
\text { and divergence } \\
\text { between the } \\
\text { qualitative and } \\
\text { quantitative results } \\
\text { demonstrated in the } \\
\text { study? }\end{array}$ & $\begin{array}{l}\text { 5. Do the different } \\
\text { components of } \\
\text { qualitative and } \\
\text { quantitative methods } \\
\text { involved adhere to } \\
\text { the quality criterion? }\end{array}$ \\
\hline 25 & $\mathrm{Y}$ & $\mathrm{Y}$ & $\mathrm{Y}$ & $\mathrm{Y}$ & $\mathrm{Y}$ \\
\hline 32 & $\mathrm{Y}$ & $\mathrm{Y}$ & $\mathrm{Y}$ & $\mathrm{C}$ & $\mathrm{Y}$ \\
\hline 39 & $\mathrm{Y}$ & $\mathrm{Y}$ & $\mathrm{Y}$ & $\mathrm{Y}$ & $\mathrm{Y}$ \\
\hline
\end{tabular}

Table 6. Data familiarisation of study under review for concept derivation

\begin{tabular}{clc}
\hline S No & Stage & Codes \\
\hline 1 & Transcript & 163 \\
2 & Preliminary thought & 142 \\
3 & Open Code & 103 \\
4 & Initial Category & 58 \\
5 & Refined Category & 40 \\
6 & Final Category & 28 \\
7 & Sub-Theme & 10 \\
8 & Themes & 8 \\
9 & Concept & 4 \\
10 & Core Concept & 1 \\
\hline
\end{tabular}

\section{RESULTS AND DISCUSSION}

In Figure 2, an association of term energy with supply and sustainable with technologies means these words are used in such combinations to derive inference from the association. Climate is associated with displacement, vulnerability, disaster and migration. Terms such as measures, allowances, companies, incentives, and usage were linking to the item efficiency. Small island developing states (SIDS) is associated with securities, adaptation, change, support, need, and lack, pinpointing SIDS' energy challenges and characteristics. Building sustainable development links to sustainable energy technologies through regulation on sustainable development, which is further related to subsidised electricity tariffs through renewable energy. The disbursement of various energy factors, energy challenges, policies, measures, SDG 7 challenge, 
connects to SIDS' energy challenge, T\&T energy challenge, Climate change challenge, which connects to energy conservation through energy conservation measures. Further, energy conservation steps lines to Sustainable development and Lifelong learning through Building sustainable development. Other than that, these Feed-in tariffs are associated with promoting sustainable energy development and adding a feed-in tariff rate. In contrast, an association of the policy-based tariff to electricity grid simulation, policy-based tariff structure and power generation and fuel dependency highlights the connectivity of electricity price with electricity consumption rates.

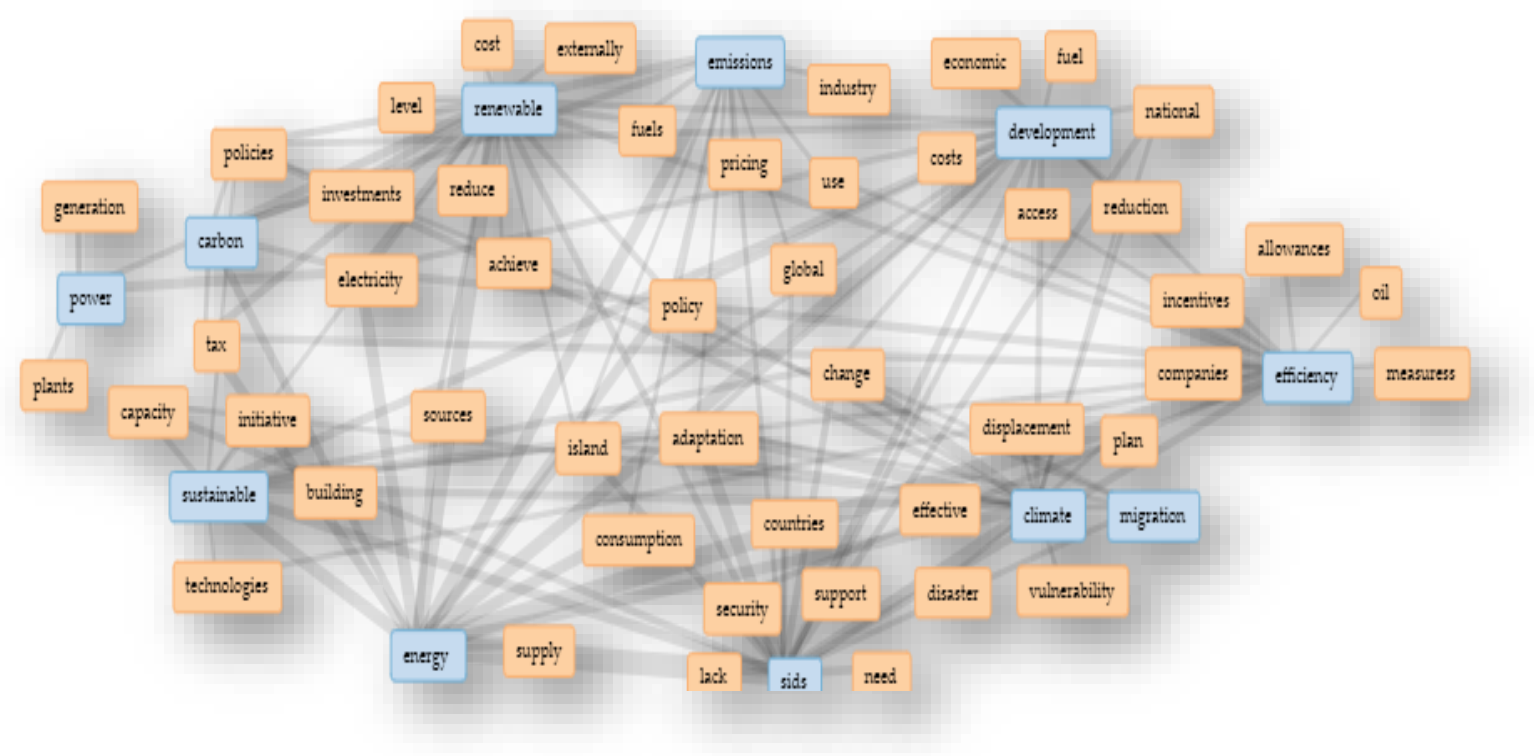

Figure 2. The conceptual lens (Voyant tools output)

In Figure 2 and Table 7, SIDS challenges link to SIDS sustainable development, Energy conservation challenges, focus on reducing greenhouse gas emissions, the carbon footprint for sustainable development, Capability building and sustainable development, and Barriers to renewable energy in SIDS. In addition, SIDS' energy challenge links to SIDS' energy efficiency sources which are further connected to the climate change challenge through SIDS' SDG challenges and are associated with institutionalising energy challenges. Table 7 quotes the most frequently used items during conceptualisation given the review objective. The items are energy-efficiency-conservation-measures $(402+57+36+41)$, residential-electricityconsumption $(45+157+74)$, renewable $(94)$, climate (54), emissions (48), SIDS-Trinidad and Tobago $(118+30+27)$ with challenges, pricing and tariff sharing an equal frequency score of 40 each.

Figure 3 shows connectivity between final categories (marked with yellow vertices) and sub-theme (marked with green vertices). As can be seen, Sustainable energy policy (SEP) is associated with Sustainable policy, Energy conservation and building code, Future energy policy, Efficiency increasing policy, SDG 7 policy challenge and consumption-based sustainable energy policy. In addition, the SEP connects to SDG7 challenges through Energy mix policy, Sustainable development goal through Sustainable development, Sustainable development goal 7 through policy for renewable energy, and sustainable energy resources through Sustainable generation resources. Another vital linkage is between Tariff structure and Tariff policy structure through Tariff policy design. The tariff structure is associated with subsidy based tariff, policybased tariff, domestic tariff, tariff structure and consumption, feed-in tariff rate. Few other connectives are iterated and shown in Figure 4.

Figure 5 shows the plot diagram between Sub-theme (marked with yellow vertices) and Theme (marked with green vertices). The edges in the black arrow create a loop between Residential energy efficiency, conservation and customer awareness through energy consumption measures and energy consumption behaviour. Another loop is between sustainable energy policy, residential energy efficiency, conservation, SDG 7, Sustainable energy, consumption-based structure and Policy design through SDG7 challenge, Sustainable development goal and Sustainable energy policy. SDG 7 is further associated with 
sustainable energy resources and Sustainable Development Goal 7. The final loop between Sustainable energy and Policy design is through Tariff structure. Figure 5 displays the conceptualisation of themes.

Figure 5 shows the link between various Themes (marked with yellow vertices) and Concepts (marked with green vertices). The loop between Sustainable energy policy and Energy policy forms through policy design and sustainable energy. Sustainable energy policy (SEP) is further associated with SDG 7, Energy awareness through consumption-based structure and energy conservation through Residential energy conservation. Energy awareness links to customer awareness, and energy policy links to Tariff structure. The link between the concepts shows that the core concept is energy conservation behaviour (ECB).

It is understandable from Table 8, Figures 4 and 5 that SEP and energy conservation are at the forefront of research in the energy sector at SIDS. While raising the bell for effective energy policies, publications have also underlined the need for energy-saving appliances and their availability at a subsidised price to sensitise the users on energy saving. Table 7 and Figure 5 highlight energy conservation and energy efficiency and their link with energy challenges. Table 9 is an outcome of monitoring the association plots and frequency tables on the energy aspect focus of the study under review.

Table 7. Item frequency $(\mathrm{F})$

\begin{tabular}{lllllllll}
\hline Sr. No & Items & F & Sr. No & Items & F & Sr. No & Items & F \\
\hline 1. & Energy & 402 & 20. & Conservation & 36 & 39. & Use & 21 \\
2. & Electricity & 157 & 21. & Demand & 34 & 40. & Access & 20 \\
3. & SIDS & 118 & 22. & Cost & 32 & 41. & Economic & 20 \\
4. & Renewable & 94 & 23. & Policies & 32 & 42. & Fuels & 20 \\
5. & Consumption & 74 & 24. & Carbon & 31 & 43. & Production & 20 \\
6. & Policy & 60 & 25. & Power & 30 & 44. & Country & 19 \\
7. & Development & 57 & 26. & Trinidad & 30 & 45. & Low & 19 \\
8. & Efficiency & 57 & 27. & Regulatory & 28 & 46. & Reduce & 19 \\
9. & Climate & 54 & 28. & Tobago & 27 & 47. & Resources & 19 \\
10. & Adaptation & 49 & 29. & Capacity & 26 & 48. & Sources & 19 \\
11. & Sustainable & 49 & 30. & Costs & 26 & 49. & National & 18 \\
12. & Emissions & 48 & 31. & Island & 26 & 50. & Solar & 18 \\
13. & Residential & 45 & 32. & Awareness & 25 & 51. & Challenge & 17 \\
14. & Change & 43 & 33. & Supply & 25 & 52. & Lack & 17 \\
15. & High & 42 & 34. & Framework & 23 & 53. & Reduction & 17 \\
16. & Measures & 41 & 35. & Gas & 23 & 54. & Based & 16 \\
17. & Challenges & 40 & 36. & Generation & 22 & 55. & Countries & 16 \\
18. & Pricing & 40 & 37. & Government & 22 & 56. & Customers & 16 \\
19. & Tariff & 40 & 38. & Need & 22 & 57. & Investments & 16 \\
\hline
\end{tabular}

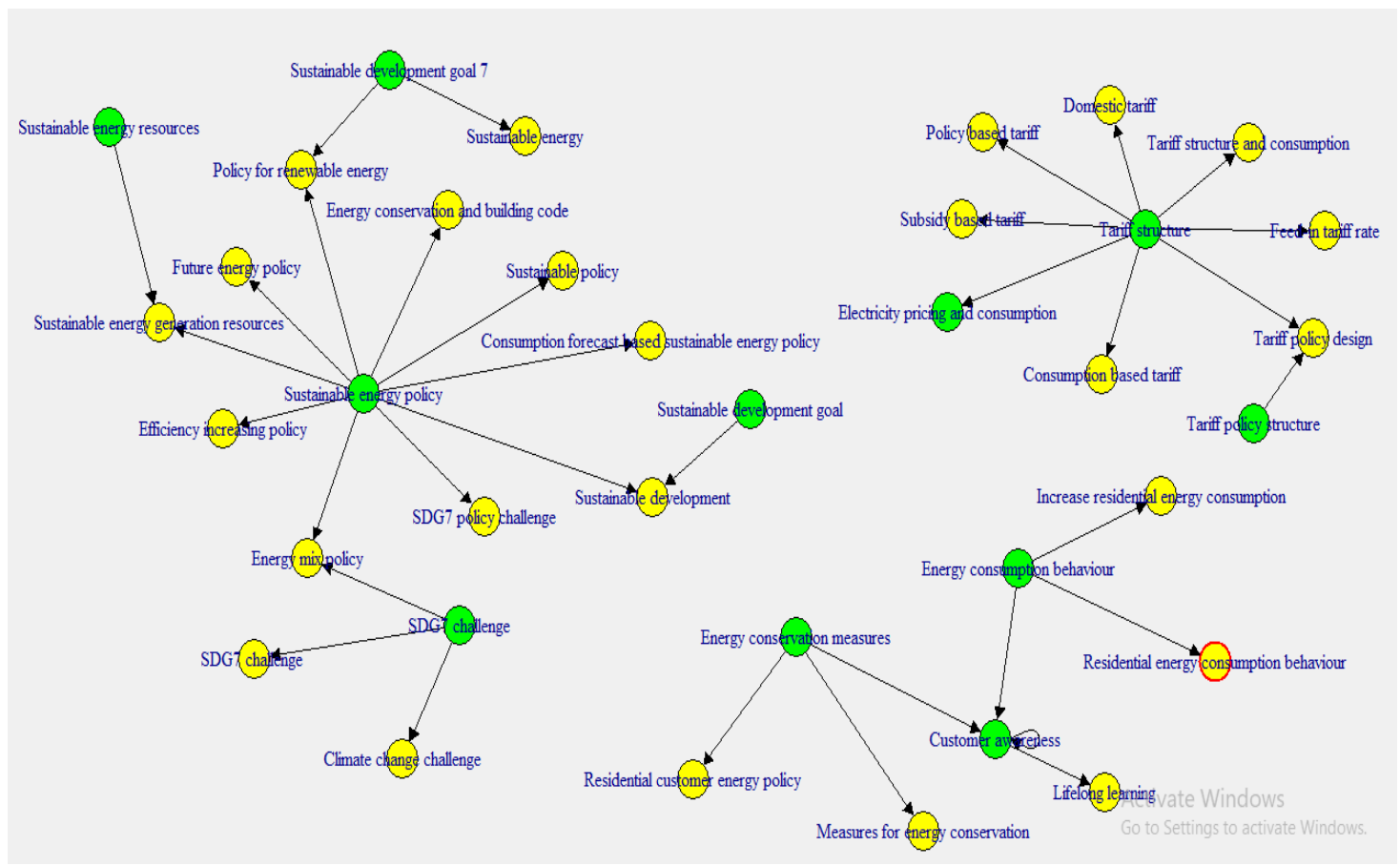

Figure 3. Relationship 1 using the fruchterman reingold layout algorithm 


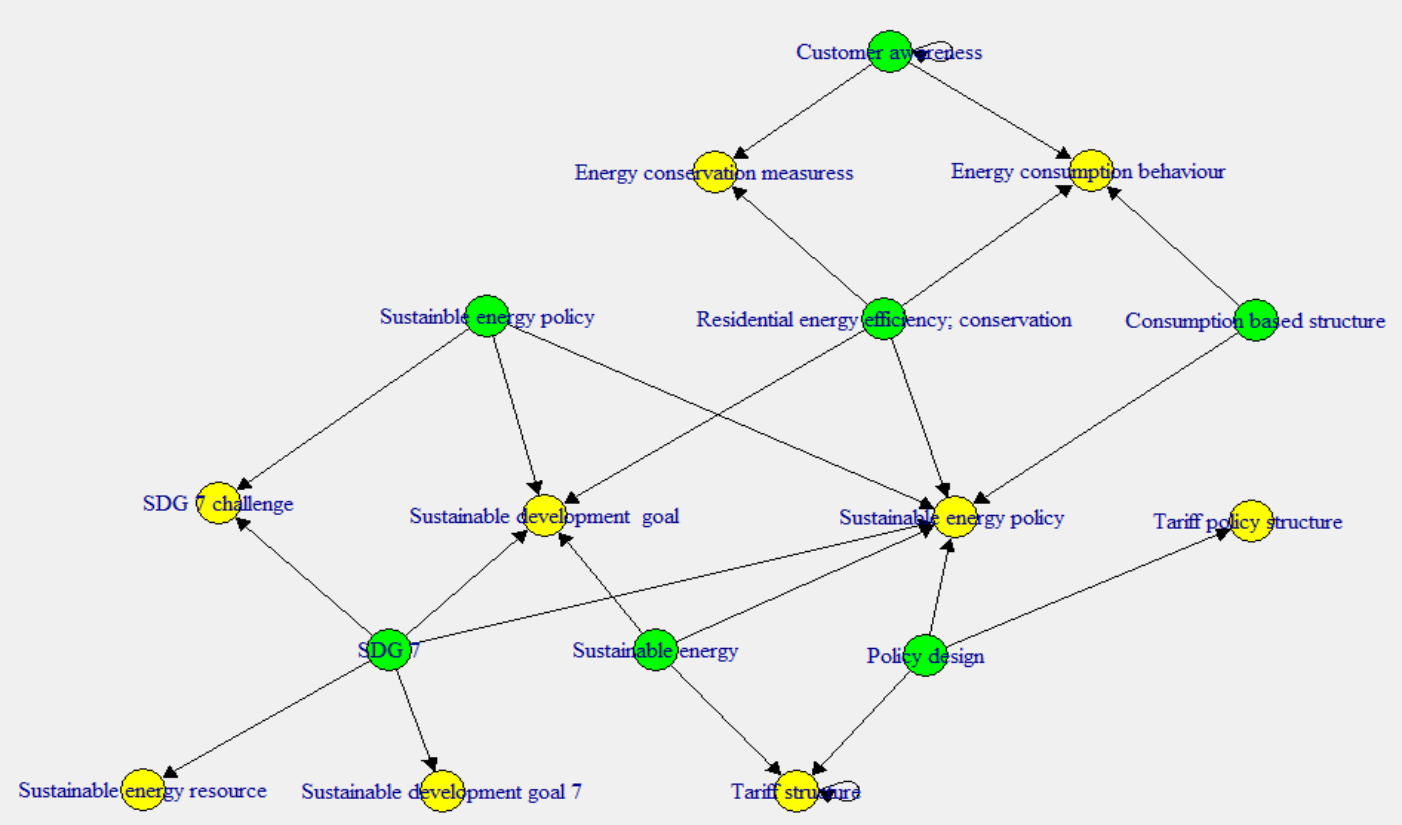

Figure 4. Relationship 2 using the fruchterman reingold layout algorithm

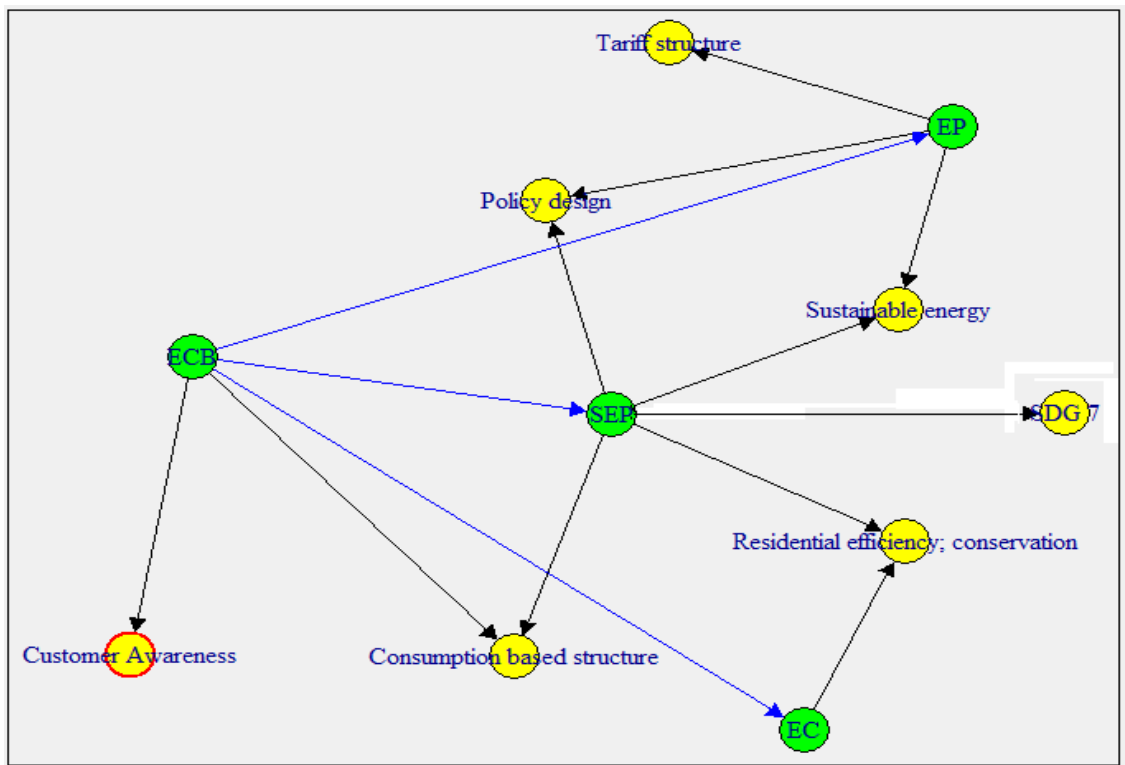

Figure 5. Relationship 3 using the fruchterman reingold layout algorithm

Table 8. Energy conservation behaviour is review core $(\mathrm{n}=19)$

\begin{tabular}{clc}
\hline S. & Identified Concept & Links Frequency \\
No. & & \\
\hline 1 & Sustainable Energy Policy & 18 \\
2 & Energy Conservation & 12 \\
3 & Energy Policy & 11 \\
4 & Energy Conservation Behaviour & 9 \\
Core: Energy Conservation Behaviour & $18+12+11=41$ \\
(9) & \\
Source Table 7 and Figure 5 & \\
\hline
\end{tabular}


Table 9. Energy aspect focus of study under review

\begin{tabular}{|c|c|c|c|}
\hline Ref No. & Energy Aspect Focus & Policy Aspect Focus & Energy Challenges Focus \\
\hline [22] & $\begin{array}{l}\text { Climate Change; Energy } \\
\text { Supply Chain Challenge }\end{array}$ & Sustainable Energy Policy & $\begin{array}{l}\text { Socio- Economic-Environment Challenges; } \\
\text { Institutional Challenges; Fund Challenges; } \\
\text { Supply Chain Challenge. }\end{array}$ \\
\hline [23] & $\begin{array}{l}\text { Levelized cost of } \\
\text { electricity (LCOE); Energy } \\
\text { Pricing Policy }\end{array}$ & $\begin{array}{l}\text { Energy Policy (Electricity } \\
\text { Pricing) }\end{array}$ & $\begin{array}{l}\text { Energy Mix Challenges; Renewable Energy } \\
\text { Challenges. }\end{array}$ \\
\hline [24] & $\begin{array}{l}\text { Climate Change; Energy } \\
\text { Efficiency; Residential } \\
\text { Electricity Demand }\end{array}$ & $\begin{array}{l}\text { Energy Efficiency; Energy } \\
\text { Conservation }\end{array}$ & $\begin{array}{l}\text { Challenge on Availability of Alternate } \\
\text { Energy Appliances; Challenge of } \\
\text { Awareness on Electricity Usage behaviour. }\end{array}$ \\
\hline [25] & $\begin{array}{l}\text { Energy Pricing Policy; } \\
\text { Tariff Structure }\end{array}$ & $\begin{array}{l}\text { Energy Policy (Electricity } \\
\text { Pricing) }\end{array}$ & Energy Mix Challenges. \\
\hline [26] & Renewable Energy & Renewable Energy & $\begin{array}{l}\text { Renewable Energy Challenges; Economic } \\
\text { Development Challenges; Energy Mix } \\
\text { Challenges; Institutional Challenges }\end{array}$ \\
\hline [27] & $\begin{array}{l}\text { Energy Mix; Renewable } \\
\text { energy }\end{array}$ & $\begin{array}{l}\text { Energy Efficiency; Energy } \\
\text { Conservation }\end{array}$ & $\begin{array}{l}\text { Challenge on Availability of Alternate } \\
\text { Energy Appliances; Challenge of } \\
\text { Awareness on Electricity Usage behaviour. }\end{array}$ \\
\hline [28] & $\begin{array}{l}\text { Climate Change; Energy } \\
\text { Efficiency; Residential } \\
\text { Electricity Demand }\end{array}$ & $\begin{array}{l}\text { Energy Efficiency; Energy } \\
\text { Conservation }\end{array}$ & $\begin{array}{l}\text { Challenge of Awareness on Electricity } \\
\text { Usage behaviour. }\end{array}$ \\
\hline [29] & Renewable Energy & Renewable Energy & Fund Challenges. \\
\hline [30] & $\begin{array}{l}\text { Energy Consumption and } \\
\text { Emissions per capita }\end{array}$ & Energy Consumption & Economic Development Challenges \\
\hline [31] & Renewable Energy & Renewable Energy & Economic Development Challenges \\
\hline [32] & $\begin{array}{l}\text { Energy Consumption and } \\
\text { Emissions per capita }\end{array}$ & Energy Consumption & Economic Development Challenges \\
\hline [33] & $\begin{array}{l}\text { Energy Supply Chain } \\
\text { challenge }\end{array}$ & $\begin{array}{l}\text { Energy Efficiency; Energy } \\
\text { Conservation }\end{array}$ & Institutional Challenges \\
\hline [34] & SIDS Energy Challenges & Sustainable Development & $\begin{array}{l}\text { Climate Change Challenges/ Environmental } \\
\text { Challenges; Economic Development } \\
\text { Challenges; Institutional Challenges }\end{array}$ \\
\hline [35] & SIDS Energy Challenges & Sustainable Development & Renewable Energy Challenges \\
\hline [36] & SIDS Energy Challenges & Sustainable Development & Institutional Challenges \\
\hline [37] & SIDS Energy Challenges & Sustainable Development & $\begin{array}{l}\text { Climate Change Challenges/ Environmental } \\
\text { Challenges; Institutional Challenges }\end{array}$ \\
\hline [38] & SIDS Energy Challenges & Sustainable Development & $\begin{array}{l}\text { Renewable Energy Challenges Institutional } \\
\text { Challenges }\end{array}$ \\
\hline [39] & $\begin{array}{l}\text { Energy Consumption and } \\
\text { Carbon Emission }\end{array}$ & Energy Consumption & $\begin{array}{l}\text { Carbon Emission and Economic growth } \\
\text { Challenge }\end{array}$ \\
\hline [40] & $\begin{array}{l}\text { Capability Building; } \\
\text { Renewable energy, }\end{array}$ & $\begin{array}{l}\text { Energy Efficiency; Energy } \\
\text { Conservation }\end{array}$ & $\begin{array}{l}\text { Socio- Economic-Environment Challenges } \\
\text { Technological Challenges; Institutional } \\
\text { Challenges. }\end{array}$ \\
\hline
\end{tabular}

The institutional hiccups and economic development challenges challenge energy Conservation. Technological challenges confer as a reflection of the inadequacy of funds to develop or buy new technologies, including energy mix [44]. Focus on energy efficiency, energy conservation, and sustainable development goes in conjunction with most studies [45]. Few studies have also advocated focusing on renewable energy electricity pricing in the country's policies [46]. Discussions have also revolved around renewable energy in few studies as one of the policy aspects focuses. Persuasively, the review findings advocate a sustainable energy policy ensuring sustainable development. An invariable concern on climate change and environmental issues anticipating a quality energy mix of renewable energy are necessary to meet the SDG-7. The T\&T sustainable energy challenge has a connection to the climate change challenge, policy challenges, environmental and economic development challenges. In addition, the energy policy joining with electricity pricing, residential consumption, energy conservation, and behavioural training shows possibilities for low energy conservation measures in the residential sector of T\&T. Comparing the review findings with T\&T's electricity consumption shows that the Caribbean average retail electricity price in 2012 was 0.33 $\mathrm{USD} / \mathrm{kWh}$. The world's average retail electricity price for the same year was $0.14 \mathrm{USD} / \mathrm{kWh}$. In June 2019, the average price of electricity in the world was 0.14 US dollars per kWh for households and 0.12 US dollars for businesses, while in T\&T, it was 0.053 US\$ per $\mathrm{kWh}$ for households and 0.053 US\$ for businesses, including various components such as the cost of power, distribution, and taxes in the electricity bill (Table 10 [46]). Table 11 [15], [46] shows the three consumption categories and tariffs for the residential sector in Trinidad and Tobago. 
Table 10. Trinidad and Tobago electricity prices

\begin{tabular}{lcc}
\hline $\begin{array}{c}\text { Trinidad and Tobago } \\
\text { electricity prices }\end{array}$ & $\begin{array}{c}\text { Household, } \\
\text { kWh }\end{array}$ & $\begin{array}{c}\text { Business, } \\
\text { kWh }\end{array}$ \\
\hline Trinidad and Tobago Dollar & 0.354 & 0.359 \\
US Dollar & 0.053 & 0.053 \\
\hline
\end{tabular}

Table 11. T\&T residential consumption category

\begin{tabular}{lc}
\hline \multicolumn{1}{c}{ Category } & Price \\
\hline $1-400 \mathrm{kWh}$ & $0.26 \mathrm{TT} \$$ \\
$401-1000 \mathrm{kWh}$ & $0.32 \mathrm{TT} \$$ \\
$>1000 \mathrm{kWh}$ & $0.37 \mathrm{TT} \$$ \\
\hline
\end{tabular}

T\&T has 431,000 household consumers; approximately 120,000 use an average of 1500 kilowatthours (kWh) bi-monthly, which is considered high compared to T\&Ts CARICOM neighbours. 32,000 households out of 4,31000 use 3000kwh per bi-monthly period. The 2017 energy report card of Trinidad and Tobago point out that the second-largest share of T\&Ts energy consumption is residential (28\%). Residential consumption is considerably high in comparison to household consumption in many other countries in the region. $43 \%$ of homes in T\&T have a consumption level that is on par with the average North American home, twice that of the average European home, and three times the global average [44]. Table 12 compares T\&T with Jamaica (CARICOM neighbour) on Energy Score [44], [46]. Jamaica, T\&T's fellow CARICOM nation, is ahead of T\&T in EE and RE focus. Therefore, it is high time that T\&T should plan Energy Efficiency efforts and implement them.

Table 12. Energy comparative chart of T\&T and Jamaica

\begin{tabular}{lcc}
\hline Comparison Base & Trinidad \& Tobago & Jamaica \\
\hline COP 15 & Y & Y \\
Population ('000,000) & 1.36 & 2.89 \\
GDP per capita ('000 USD) & 32.3 & 9.4 \\
Mature Energy Production Assets & Y & - \\
Downstream Petrochemical Industry & $\mathrm{Y}$ & - \\
LNG Producer/Exporter & $\mathrm{Y}$ & - \\
Energy Policy Established & - & $\mathrm{Y}$ \\
Implemented Energy Efficiency Initiative & - & $\mathrm{Y}$ \\
Renewable Energy & - & $\mathrm{Y}$ \\
Energy Intensity per capita (MJ/USD & 19.1 & 5.2 \\
2011 PPP) & & \\
\hline
\end{tabular}

\section{CONCLUSION}

The review concludes that the main grounds towards the advancement of an initiative to achieve energy conservation in $\mathrm{T} \& \mathrm{~T}$ is on the following counts: (a) reducing household electricity consumption by developing an energy conservation culture, (b) focused energy efficiency policy specifically targeting overcoming energy challenges, implementing renewable energy, and providing awareness and training to develop energy conservation culture. Information on the considerable energy saving potential daily, irrespective of how efficient the facility may be, is essential to develop an energy conservation culture. For example, experience shows that anybody can easily save $50 \mathrm{~W}$ of electrical power daily in the airconditioning application without compromising comfort. If 140000 people living in T\&T (about $10 \%$ of the population) save $50 \mathrm{~W}$ daily, then the total saving will be $7 \mathrm{MW}$ at the consumer end available on the grid for consumption. Going by the Rule of 1 unit saving at the consumer end is equal to 2 units saving at the generation point, it will mean $14 \mathrm{MW}$ savings at the generating stations. Savings of $14 \mathrm{MW}$ is free of cost, instantaneous, and without any environmental impact. The study outcomes are a good reference on LCECM for referencing Building Codes for residential buildings in Trinidad and Tobago with energy conservation. Furthermore, the energy conservation culture can contribute to Trinidad's commitment to attaining SDG-7 through training in awareness and low-cost energy conservation measures.

\section{REFERENCES}

[1] J. T. Roberts, P. E. Grimes and J. L. Manate, "Social Roots of Global Environmental Change: A World-Systems Analysis of $\mathrm{CO}_{2}$ Emissions," Journal of World-Systems Research, pp. 277-315, 2003, doi: 10.5195/jwsr.2003.238.

[2] R. K. Tyagi, and N. Vasijeviene, "The case of CSR and irresponsible management practices," Competitiveness Review, vol. 23, no. 4/5, pp. 372-383, 2013, doi: 10.1108/CR-03-2013-0031.

[3] R. Tyagi, S. Vishwakarma, K. K. Singh, and C. Syan, "Low-Cost Energy Conservation Measures and Behavioral Change for Sustainable Energy Goal," Affordable and Clean Energy, Encyclopedia of the UN Sustainable Development Goals, Springer, 2020, doi: 10.1007/978-3-319-71057-0155-1.

[4] R. Tyagi, S. Vishwakarma, Z. S. Alexandrovich, and S. Mohammed, "ICT Skills for Sustainable Development Goal 4,” Quality Education Encyclopedia of the UN Sustainable Development Goals, 2020. 
[5] R. Tyagi, S. Vishwakarma, "Post-reforms training needs of frontline managers in Indian power distribution companies: A top managers' perspective," International Journal of Energy Sector Management, vol. 11, no. 3, pp. 416-425, 2017, doi: 10.1108/IJESM-02-2016-0001.

[6] R. Tyagi, S. Vishwakarma, and S. S. Yadav, "Community Self-Help Projects," Encyclopedia of the UN Sustainable Development Goals, Springer, 2021, doi: 10.1007/978-3-319-69625-6.

[7] F. K. Donkor, and K. Mearns, "Clean Energy Solutions and Sustainable Development," Affordable and Clean Energy, Encyclopedia of the UN Sustainable Development Goals, 2020, doi: 10.1007/978-3-319-71057-084-1.

[8] R. P. Bellany, "Liberalism: Impact on Social Science, "International Encyclopedia of the Social \& Behavioral Sciences, pp. 8797-8801, 2001, doi: 10.1016/B0-08-043076-7/00107-8.

[9] R. Tyagi, S. Vishwakarma, M, Rishi, and S. Rajiah, "Reducing Inequalities Through Education and Skill Development Courses," Encyclopedia of the UN Sustainable Development Goals, Springer, 2020.

[10] IEA, "Transition to Sustainable Buildings: Strategies \& Opportunities to 2050," International Energy Agency, 2013. [Online]. Available: https://iea.blob.core.windows.net/assets/1e300ab6-44de-41dc-8714ee12a4800943/Building2013_free.pdf.

[11] Ali S. S., R. Tyagi and Chauhan R, "Energy conservation project funding in commercial building: An expenditure or investment?" International Journal of Power Electronics and Drive Systems, 2019, doi: 10.11591/ijpeds.v10.i1.pp504-513 .

[12] S. Goubran, T. Masson and M. Caycedo, "Evolutions in Sustainability and Sustainable Real Estate," Sustainable Real Estate, Cham (Switzerland): Palgrave Macmillan, pp: 11-31, 2019, doi: 10.1007/978-3-319-94565-1_3.

[13] K. Bataineh, and A. Alrabee, "Improving the Energy Efficiency of the Residential Buildings in Jordan," Buildings, vol. 8, no. 85, pp. 1-16, 2018, doi: 10.3390/buildings8070085.

[14] SS. Ali and T. Ruchi, "The role of Energy Conservation Building Code 2017 in Indian Energy Policy," International Journal of Recent Technology and Engineering IJRTE, vol. 9, no. 1, pp. 1799-1806, 2017, doi: 10.35940/ijrte.A2212.059120.

[15] TRIC, "Energy Road Map Series-Advancing Energy Efficiency/ Energy Conservation in Trinidad and Tobago," Trinidad Regulatory Industries Commission, June 2019.

[16] Onwuegbuzie, J. Anthony, L. N. Leech, and M. T. K. C. Kathlee, "Qualitative Analysis Techniques for the Review of the Literature," The Qualitative Report, vol. 17, no. 28, pp. 1-28, 2012, doi: 10.46743/2160-3715/2012.1754.

[17] H. Snyder, "Literature review as a research methodology: An overview and guidelines," Journal of Business Research, vol. 104, pp. 333-339, 2019, doi: 10.1016/j.jbusres.2019.07.039.

[18] D. Tranfield, D. Denyer and P. Smart, "Towards a methodology for developing evidence-informed management knowledge by means of systematic review," British Journal of Management, vol. 14, no. 3, pp. 207-222, 2003.

[19] P. M. Podsakoff, S. B. Mackenzie, D. G. Bachrach, and N. P. Podsakoff, "The Influence of Management Journals in 1980s and 1990s," Strategic Management Journal, vol. 26, no. 5, pp. 473-488, doi: 10.1002/smj.454.

[20] H. Q. Nha et al., "Mixed Methods Appraisal Tool (MMAT), Version 2018 for information professionals and research," Education for Information, vol. 34, no. 4, pp. 285-291, 2018, doi: 10.3233/EFI-180221.

[21] R. Tyagi, "Meerut Embroidery Cluster: A Case Study," South Asian Journal of Business and Management Cases, vol. 1, no. 2, pp. 185-202, 2013, doi: 10.1177/2277977912459445.

[22] A. Atteridge, and G. Savvidou, "Development Aid for Energy in Small Island Developing States," Energy, Sustainability and Society, vol. 9, no. 10, pp. 1-10, 2019, doi: 10.1186/s13705-019-0194-3.

[23] X. T. Chadee, and R. M. Clarke, "Wind resources and the Levelized cost of wind-generated electricity in the Caribbean islands of Trinidad and Tobago," Renewable and Sustainable Energy Reviews, vol. 81, Part 2, pp. 25262540, 2018, doi: 10.1016/j.rser.2017.06.059.

[24] A. Chunekar, S. Varshney, and S. Dixit, "Residential Electricity Consumption in India: What do we know?" Prayas (Energy Group), vol. 81, pp. 765-778, 2016, doi: 10.1016/J.ENECO.2019.05.021.

[25] R. Hlendik, and J. Lazar, "Distribution System Pricing for Customers with Distributed Energy Resources," Future Electric Utility Regulation Series, Lawrence Berkeley National Laboratory, vol. 4, pp. 1-103, 2016.

[26] Z. Khan, K. Siriram, and K. Greigg, "Fiscal incentives promoting REEE measures in Trinidad and Tobago," World J. Sci., Tech. and Sustainable Development, vol. 11, no. 3, pp. 196-213, 2014, doi: 10.1108/wjstsd-06-2014-0013.

[27] C. Klock, and P. D. Nunn, "Adaptation to Climate Change in Small Island Developing States: A Systematic Literature Review of Academic Research," The Journal of Environment \& Development, vol. 28, no. 2, pp. 196$218,2019$.

[28] A. G. Kok, K. Shang, and S. Yucel, "Impact of electricity pricing policies on renewable energy investments and carbon emissions," Management Science, vol. 64, no. 1, pp. 131-148, 2016, doi: 10.1287/mnsc.2016.2576.

[29] F. Krausmann, R. Richter and N. Eisenmenger, "Resource Use in Small Island States," Journal of Industrial Ecology, vol. 18, no. 2, pp. 294-305, 2014, doi:10.1111/jiec.12100.

[30] K. K. Perry, "The Dynamics of Industrial Development in a Resource-Rich Developing Society: A Political Economy Analysis," J. Dev. Soc., SAGE Publication, vol. 34, no. 3, pp. 264-296, 2018, doi: 10.1177/0169796x18786136.

[31] J. Pillai, and C. Riverol, "Estimation of gas emission and derived electrical power generation from landfills. Trinidad and Tobago as study case," Sustainable Energy Technologies and Assessments, vol. 29, pp. 139-146, 2018.

[32] P. Raghoo, D. Surroop, F. Wolf, W. L. Filho, P. Jeetah, B. Deakowitz, "Dimensions of energy security in Small Island Developing States," Utilities Policy, vol. 53, pp. 94-101, 2018, doi: 10.1016/j.jup.2018.06.007. 
[33] S. Robinson, "A richness index for baselining climate change adaptations in small island developing states," Environmental and Sustainability Indicators, vol. 8, no. 100065, 2020, doi: 10.1016/j.indic.2020.100065.

[34] R. Shirley, and D. Kammen, "Renewable energy sector development in the Caribbean: Current trends and lessons from history," Energy Policy, vol. 57, pp. 244-252, 2013, doi: 10.1016/j.enpol.2013.01.049.

[35] D. Surroop, P. Raghoo, F. Wolf, K. U. Shah, and P. Jeetah, "Energy access in Small Island Developing States: Status, barriers and policy measures," Environmental Development, vol. 27, pp. 58-69, 2018.

[36] A. Thomas, A. Baptiste, R. M. Koller, P. Pringle, and K. Rhiney, "Climate Change and Small Island Developing States," Annual Review of Environment and Resources, vol. 45, no. 1-27, 2020.

[37] A. Thomas, and L. Benjamin, "Policies and mechanisms to address climate-induced migration and displacement in Pacific and Caribbean small island developing states," International Journal of Climate Change Strategies and Management, Emerald Publication, vol. 10 no. 1, pp. 86-104, 2018, doi: 10.1108/IJCCSM-03-2017-0055.

[38] R. Waheed, S. Sarwar, and C. Wei, "The survey of economic growth, energy consumption and carbon emission," Energy Reports, vol. 5, pp. 1103-1115, 2019, doi: 10.1016/J.EGYR.2019.07.006.

[39] F. Wolf, D. V. Becker, W. Leal, J. Krink, J. Haseberger, and M. Kowald, "Sustainable energy generation and use in SIDS and beyond-introducing the L3EAP online learning approach," Brazilian Journal of Science and Technology, vol. 3, no. 2, pp. 1-14, 2016, doi: 10.1186/s40552-016-0021-8.

[40] Q. N. Hong et al, "Improving the content validity of the mixed methods appraisal tool: a modified e-Delphi study," Journal of Clinical Epidemiology, vol. 111, pp. 49-59, 2019, doi: 10.1016/j.jclinepi.2019.03.008.

[41] L. S. Vygotsky, "Thought and language," The MIT Press, 2012.

[42] J. Smith, and J. Firth, "Qualitative data analysis: application of the framework approach," Nurse Researcher, vol. 18, no. 2, pp. 52-62, 2011, doi: 10.7748/nr2011.01.18.2.52.c8284.

[43] R. Huang, "RQDA: R-based Qualitative Data Analysis," R package version 0.2-8, [Online] Available: http://rqda.rforge.r-project.org

[44] L. Barredo, "Mainstreaming Renewables in the Caribbean Energy Mix," Article dated, 2015, The UN Sustainable Development Solutions Network (SDSN),

[Online]

Available:https://www.unsdsn.org/news/2015/08/05/mainstreaming-renewables-in-the-caribbean-energy-mix

[45] Tracking SDG7, “The Energy Progress Report 2018,” World Bank Group, 2018.

[46] Caricom, "Caribbean Center for Renewable Energy and Energy Efficiency," 2015, [Online] Avalilable: https://caricom.org/institutions/caribbean-center-for-renewable-energy-and-energy-efficiency-ccreee/.

\section{BIOGRAPHIES OF AUTHORS}

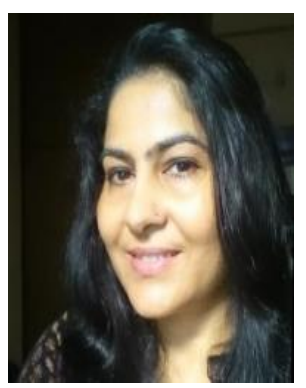

Dr. Ruchi Tyagi is Senior Associate Professor, Department of General Management, Faculty of HR \&OB, School of Business, University of Petroleum and Energy Studies, Dehradun, India. She holds a degree in science, MBA (HR), PhD (Management) and Postdoc on the project, "Low-cost Conservation Measures for Energy Conservation in the residential sector of Trinidad and Tobago", collaborated by the Ministry of Planning and Development, St Augustine, Trinidad and Tobago, West Indies. Dr Ruchi is also an Adjunct Professor (Honorary) in the Utilities Engineering Department of the University of Trinidad and Tobago (2021) and Honorary Prof. to the Nizhny Novgorod Institute of Management and Business (2013). In addition, she was an invited speaker at a seminar of IET-UK in Vancouver, Canada; Department of Ethics at Moscow State University, Nizhny Novgorod Institute of Management and Business, Leningrad State University, Vladimir University, Russian Federation. Email: rtyagi@ddn.upes.ac.in, csractivist@yahoo.co.uk; ORCID ID: 0000-0002-6412-3216; Scopus Id55008387700; Google Scholar Id: 54bdvj8AAAAJ\&hl

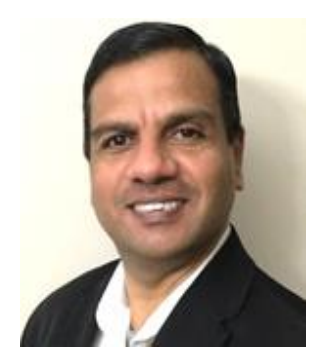

Dr Suresh Vishwakarma is Adjunct Professor, Department of Utilities Engineering, University of Trinidad and Tobago. He holds a degree in electrical engineering, MBA, and PhD in Power Management. He has undertaken Postdoctoral research on an energy efficiency project at the University of West Indies. Suresh has held senior engineering and managerial positions in public utility companies since 1988. He is currently a Senior Engineer for a consulting company in Vancouver, Canada providing engineering services to BC Hydro. Suresh has authored 30 conference papers in America, Canada, UK, and many other countries. His research papers were publish in Emerald and Springer journals. He is an Adjunct Professor at the University of Trinidad and Tobago and Chairman of Chartered Engineers Pacific, Vancouver, Canada. ORCID ID: 00000002-2171-8770; Email: sureshvishwakarma@ hotmail.com; suresh.vishwakarma@utt.edu.tt. 